\title{
Evaluating the effect of ration composition on income over feed cost and milk yield
}

\author{
M. H. Buza, ${ }^{1}$ L. A. Holden, R. A. White, and V. A. Ishler \\ Department of Animal Science, The Pennsylvania State University, University Park 16802
}

\begin{abstract}
Feed is generally the greatest expense for milk production. With volatility in feed and milk markets, income over feed cost (IOFC) is a more advantageous measure of profit than simply feed cost per cow. The objective of this study was to evaluate the effects of ration cost and ingredient composition on IOFC and milk yield. The Pennsylvania State Extension Dairy Team IOFC tool (http://extension.psu.edu/animals/dairy/businessmanagement/financial-tools/income-over-feed-cost/ introduction-to-iofc) was used to collect data from 95 Pennsylvania lactating dairy cow herds from 2009 to 2012 and to determine the IOFC per cow per day. The data collected included average milk yield, milk income, purchased feed cost, ration ingredients, ingredient cost per ton, and amount of each ingredient fed. Feed costs for home-raised feeds for each ration were based on market values rather than on-farm cost. Actual costs were used for purchased feed for each ration. Mean lactating herd size was $170 \pm 10.5$ and daily milk yield per cow was $31.7 \pm 0.19 \mathrm{~kg}$. The mean IOFC was $\$ 7.71 \pm$ $\$ 1.01$ cost per cow, ranging from $-\$ 0.33$ in March 2009 to $\$ 16.60$ in September 2011. Data were analyzed using a one-way ANOVA in SPSS (IBM Corp., Armonk, NY). Values were grouped by quartiles and analyzed with all years combined as well as by individual year. Purchased feed cost per cow per day averaged $\$ 3.16 \pm$ $\$ 1.07$ for 2009 to 2012. For 2009 to 2012 combined, milk yield and IOFC did not differ with purchased feed cost. Intermediate levels (quartiles 2 and 3) of forage cost per cow per day between $\$ 1.45$ and $\$ 1.97$ per cow per day resulted in the greatest average IOFC of $\$ 8.19$ and the greatest average milk yield of $32.3 \mathrm{~kg}$. Total feed costs in the fourth quartile ( $\$ 6.27$ or more per cow per day) resulted in the highest IOFC. Thus, minimizing feed cost per cow per day did not maximize IOFC. In 2010 , the IOFC was highest at $\$ 8.09$ for dairies that fed 1 or more commodity by-products. Results of the study
\end{abstract}

\footnotetext{
Received October 18, 2013.

Accepted January 17, 2014

${ }^{1}$ Corresponding author: buza.marianne@gmail.com or mhb165@ psu.edu
}

indicated that intermediate levels of forage cost and higher levels of total feed cost per cow per day resulted in both higher milk yield and higher IOFC. This suggests that optimal ration formulation rather than least cost strategies may be key to increasing milk yield and IOFC, and that profit margin may be affected more by quality of the feed rather than the cost.

Key words: income over feed cost, profitability, dairy management

\section{INTRODUCTION}

Income for a dairy producer can be difficult to predict because milk and feed markets are continuously changing and this is exacerbated with the ever-changing prices of fuel, fertilizers, and crop seeds (CME Group Inc., 2013). Thus, producers should monitor profit margins rather than milk income or feed costs to predict profitability. Milk production is often monitored because higher milk production equates to higher milk income. However, monitoring gross milk income per cow alone does not provide a good estimate of cash flow or profitability, especially when feed costs are high. Wolf (2010) showed that income over feed cost (IOFC) could be used to monitor profit by including gross milk income and feed cost. Using IOFC accounts for the volatility in milk and feed markets, giving the producer a better metric for evaluating profit margin.

Income over feed cost is the measure of what remains of the milk income after subtracting the feed cost of the lactating cows on a per-cow-per-day basis or on a perhundredweight basis. Income over feed cost can be used to evaluate nutrition and pasture management as well. Profit margin risk management, in part, can be done by monitoring IOFC (Bozic et al., 2012). Using the Penn State IOFC tool (Ishler et al., 2013), the amount spent on purchased feeds or the cost of home-raised feeds can be evaluated against the current milk production. In grazing herds, the IOFC can be used as a measure on how well feeding strategies are being implemented (Vibart et al., 2012). Monitoring IOFC monthly can determine if feed costs are in line for the current milk production or if ration and feed management strategies are currently successful (Maulfair et al., 2011). 
With volatility in milk prices, producers examine ways to stabilize their incomes. The livestock gross margin (LGM) for the dairy cattle insurance program was developed to help protect producers from large losses in a volatile market (CME Group Inc., 2013). Research has been conducted to find the optimal LGM coverage and the best incorporation into farm management decisions (Valvekar et al., 2010, 2011; Bozic et al., 2012). Farms can improve risk management by using LGM insurance program and monitoring the IOFC.

The research objective of this study was to evaluate the effect of ration composition and ration cost on both the IOFC and milk yield. By evaluating ration characteristics and feed costs for herds with the highest IOFC and milk yield, the best management practices could be identified. The use of IOFC can lead to finding the best cost ration for the lactating herd. Continuous monitoring of IOFC should be coupled with a cash flow plan to determine the particular farm's breakeven IOFC. Only then will constant monitoring of IOFC be ideally meaningful to a producer and the impact on profitability.

\section{MATERIALS AND METHODS}

\section{IOFC Tool}

The IOFC tool was developed by Pennsylvania State University faculty, Extension educators, and staff. Information about the tool can be found on the Pennsylvania State University Dairy Extension Team website (http://extension.psu.edu/animals/dairy/businessmanagement/financial-tools/income-over-feed-cost/ introduction-to-iofc). The tool is an Excel spreadsheet (Microsoft Corp., Redmond, WA) that is user friendly. In this tool, IOFC is calculated by the following formula:

[daily average milk production (lbs)/cow $\times$ milk price per hundredweight/100] - total feed cost/cow.

Because feed costs are constantly changing, monitoring the IOFC can help dairy producers monitor margins versus just milk income or feed cost. The IOFC tool divides feed into purchased and home raised categories. The IOFC can be calculated using the market values for a feed type or the actual cost. To best compare across all the farms, market prices for home-raised feeds were used (Bailey et al., 2009; Ishler, 2012). This allows the use of market prices to be compared with the true cost of home-raised feeds. Often true costs for each individual home-raised feed are unknown by the producer, also leading to the use of market values for home-raised feeds. For the current study, all feed prices were calculated using market values from the Pennsylvania State University Extension website (http://extension.psu. edu/animals/dairy/business-management/feed-pricelist). These prices were calculated including transportation charges and profit that could be captured selling the crops rather than using them to produce milk. This website is linked to the IOFC tool and updates the monthly market prices to each IOFC worksheet. The prices for home-raised feeds reflect the value out of the structure, but do not reflect adjustments based on DM, forage, or feed quality (Ishler, 2012). These were updated with the tool and the website on a monthly basis.

\section{Data Collected}

All farms in this study were located in Pennsylvania. These farms were self-selected from the farms that chose to use the IOFC tool and completed training with the tool as part of an Extension education program. The IOFC data forms were completed by the producer and were submitted to a dairy Extension team member. The IOFC spreadsheet data includes gross milk price, average milk yield, average milk shipped, home-raised, and purchased feed amount, cost per ton of feed, batch weights of feed, number of lactating cows, and number of lactating nutritional cow groups. Data from the forms were used to calculate IOFC with the IOFC tool monthly on a cost-per-cow-per-day basis.

On the IOFC data form, producers reported total milk weights shipped for the month, the average pickup weight, or the average per-cow-per-day milk weight. If the average bulk tank weight was given, the weight was divided by the number of lactating cows and the number of days in the shipment. The major variables analyzed were milk income, feed cost, milk yield $(\mathrm{kg})$, IOFC, purchased feed cost, number of lactating animals, purchased feed amount $(\mathrm{kg})$, total feed amount $(\mathrm{kg})$, and number of lactating cow groups. All feed variables were expressed on an as-fed and per-cow-perday basis. Each ingredient was also classified as forage, concentrate grain, concentrate mix, by-product or mineral, and additive. The kilograms fed on an as-fed basis and price per ton was recorded for each feed. Only those by-products used as a commodity were included in the by-product calculations. By-products existing in premixed purchased feeds were not analyzed. The analysis for by-products was divided into 2 groups. These groups were farms that did not use by-product commodity feeds in the lactating cow ration and farms that did use by-product commodity feeds in the lactating cow ration. Feeds that fit into more than one type of analysis were analyzed for all of the analyses they were applicable for. Because by-products can often be 
categorized as multiple feed types, forage substitute byproducts were included in the forage cost analysis and purchased feed cost analysis.

\section{Statistical Analyses}

Statistical analysis was completed using one-way ANOVA tests within the SPSS program (IBM Corp., 2012). The ANOVA was conducted for total feed cost, forage cost, purchased feed cost, and inclusion of commodity by-products against milk yield and IOFC. Variables were grouped by cost quartiles of the feed and analyzed using combined data from years 2009 to 2012, in addition to analysis of the individual years 2009, 2010, and 2011. No separate analysis was conducted for the year 2012 due to the small sample size. The quartiles were created to have the same number of months of data in each quartile when the years were combined from 2009 to 2012. This created 4 ranges of feed cost. When the individual years were analyzed, the quartiles remained the same, despite differing numbers for those quartiles. A Tukey mean separation test (IBM Corp., 2012) was also used to analyze the data.

\section{RESULTS AND DISCUSSION}

Results for the 95 herds analyzed had a mean lactating herd size of $170 \pm 10.55$ and milk yield of $31.7 \pm$ $0.19 \mathrm{~kg}$ (Table1). The mean IOFC was $\$ 7.71 \pm \$ 1.01$ ranging from $-\$ 0.33$ in March 2009 to $\$ 16.60$ in September 2011. The mean number of lactating groups was $1.41 \pm 0.046$ (Table 1). It should be noted that these data are from a self-selected group of farms; therefore, it is a nonrandom sampling. Further sampling to create a larger or more normalized distribution of either farms or milk yield may lead to slightly different results.

Purchased feed cost per cow per day averaged $\$ 3.16$ $\pm \$ 1.07$ from 2009 to 2012. Milk yield and IOFC did not differ with purchased feed cost, suggesting that purchased feed cost per cow was not a key factor in high milk yield (Tables 2 and 3). This was in contrast to popularly held beliefs that high purchased feed cost will result in a lower profit margin. Data from this study showed that the amount of purchased feed had no effect on IOFC in the combined years 2009 to 2012 or the individual years of 2009, 2010, and 2011. This does not imply that the producer who purchases high percentages of their feed may not be at risk of considerable income loss due to market changes (CME Group Inc., 2013; USDA-NASS, 2013).

Dairies that fed 1 or more commodity by-products had no difference in IOFC $(P>0.05)$ for the combined years for 2009 to 2012. However, in 2010, the IOFC was highest $(P<0.01)$ for dairies that fed 1 or more commodity by-products. No difference for the inclusion of commodity by-product was found for the individual years of 2009 and 2011. The inclusion of commodity by-products resulted in higher $(P<0.001)$ milk yield when analyzed from 2009 to 2012 and a higher $(P<$ 0.001 ) milk yield in the individual year 2010 (Table 4 ). For 2009 and 2011, no differences $(P>0.05)$ existed in milk yield with or without by-products in the ration. In a previous study, Grasser et al. (1995) found that use of whole cotton seed, wet brewers grain, wet citrus pulp, wet corn gluten feed, corn gluten meal, dried beet pulp, pressed citrus pulp, almond hulls, and rice bran decreased total feed costs. However, milk yield and IOFC were not analyzed in that study.

Intermediate levels of forage cost between $\$ 1.45$ and $\$ 1.96$ per cow per day resulted in the highest $(P<0.01)$ average IOFC of $\$ 8.19$ for the analysis for the combined years 2009 to 2012 . Forage cost between $\$ 1.45$ and 1.96 per cow per day also resulted in higher IOFC in 2010 $(P<0.001)$ and $2011(P<0.05)$ when the years were analyzed individually (Figure 1). The intermediate quartiles had the highest $(P<0.05)$ average milk yield of $32.3 \mathrm{~kg}$ for analysis for the combined years 2009 to 2012. When the years were analyzed individually, the 2009 forage cost quartile of $\$ 0.78$ to $\$ 1.44$ resulted in lower milk yield $(P<0.05)$. In 2011 , forage costs of

Table 1. Number of lactating cows, lactating cow groups, milk production, gross milk price, feed cost per cow per day, income over feed cost (IOFC), and total milk income for 95 farms from combined years 2009 to 2012 $(\mathrm{n}=500)$

\begin{tabular}{lcccc}
\hline Item & Mean & Minimum & Maximum & SEM \\
\hline Number of lactating cows & 170 & 20 & 1,475 & 10.5 \\
Number of lactating cow groups & 1.4 & 1 & 7 & 0.046 \\
Milk production (kg/cow per day) & 31.52 & 18.19 & 50.57 & 0.153 \\
Gross milk price $(\$ / C W T)$ & 19.07 & 11.75 & 25.39 & 0.124 \\
Feed Cost $(\$ /$ cow per day) & 5.63 & 2.92 & 9.20 & 0.044 \\
IOFC $(\$ /$ cow per day) & 7.71 & -0.33 & 16.60 & 0.101 \\
Milk income $\$$ / cow per day) & 13.33 & 3.94 & 20.91 & 0.115 \\
Purchased feed amount $^{1}(\mathrm{~kg} /$ cow per day) & 10.55 & 0.83 & 50.80 & 0.911 \\
Total feed amount $^{1}(\mathrm{~kg} /$ cow per day) & 45.71 & 25.0 & 75.68 & 0.578 \\
\hline
\end{tabular}

${ }^{1}$ On an as-fed basis. 
Table 2. The ANOVA of quartiles of purchased feed cost against income over feed cost (IOFC) of that ration for the years 2009 through 2012 together and each year individually $(\mathrm{n}=500)$

\begin{tabular}{|c|c|c|c|c|}
\hline \multirow[b]{2}{*}{ Item } & \multicolumn{4}{|c|}{ Feed cost quartile $^{1}$} \\
\hline & $\$ 0.79-\$ 2.47$ & $\$ 2.48-\$ 3.13$ & $\$ 3.14-\$ 3.81$ & $\$ 3.81-\$ 7.61$ \\
\hline \multicolumn{5}{|c|}{ Purchased feed cost $2009-2012^{2}$} \\
\hline $\mathrm{n}$ & 129 & 121 & 125 & 125 \\
\hline Mean IOFC (\$) & 7.73 & 7.34 & 7.94 & 7.81 \\
\hline SEM & 0.179 & 0.211 & 0.184 & 0.226 \\
\hline \multicolumn{5}{|c|}{ Purchased feed cost $2011^{2}$} \\
\hline $\mathrm{n}$ & 38 & 52 & 46 & 62 \\
\hline Mean IOFC (\$) & 8.33 & 8.58 & 9.17 & 8.74 \\
\hline SEM & 0.276 & 0.244 & 0.238 & 0.262 \\
\hline \multicolumn{5}{|c|}{ Purchased feed cost $2010^{2}$} \\
\hline $\mathrm{n}$ & 74 & 43 & 54 & 32 \\
\hline Mean IOFC (\$) & 7.46 & 7.50 & 7.48 & 8.22 \\
\hline SEM & 0.180 & 0.216 & 0.207 & 0.363 \\
\hline \multicolumn{5}{|c|}{ Purchased feed cost $2009^{2}$} \\
\hline $\mathrm{n}$ & 15 & 26 & 12 & 17 \\
\hline Mean IOFC (\$) & 4.86 & 4.61 & 5.11 & 4.86 \\
\hline SEM & 0.303 & 0.445 & 0.665 & 0.719 \\
\hline
\end{tabular}

${ }^{1}$ The purchased feed costs were divided into 4 quartiles for when all the years were combined. The quartiles remained the same for each individual year analysis.

${ }^{2}$ Purchased feed cost resulted in no significant difference $(P>0.05)$ in IOFC.

$\$ 1.97$ to $\$ 3.82$ had lower milk yield (Figure $2 ; P<$ 0.05). This suggests that optimal ration formulation was key to increasing milk yield and IOFC. Although many factors exist, such as genetics, reproductive efficiency, and management practices, that affect milk yield and, therefore, IOFC, this study focused only on data related to feeds and feeding management. When a ration does not have a high enough forage cost, such as rations on the farms falling into the first quartile, there may not be enough forage in the ration or the forage being fed is of low quality. Farms with high forage cost may have excess forage in the ration. Also, these farms could have high forage-based diets. Diets that contain high-moisture forage may have the higher forage cost because high-moisture forage is more expensive and the analysis is on an as-fed basis and not a DM basis. Forage cost has also increased because of an increased dependence on purchased forage on some farms. This is not common on Pennsylvania dairy farms but is more common in other areas of the country. A previous

Table 3. The ANOVA of quartiles of purchased feed cost against milk yield of that ration for the years 2009 through 2012 together and each year individually $(\mathrm{n}=500)$

\begin{tabular}{|c|c|c|c|c|}
\hline \multirow[b]{2}{*}{ Item } & \multicolumn{4}{|c|}{ Feed cost quartile ${ }^{1}$} \\
\hline & $\$ 0.79-2.47$ & $\$ 2.48-3.13$ & $\$ 3.14-3.81$ & $\$ 3.81-7.61$ \\
\hline \multicolumn{5}{|c|}{ Purchased feed cost 2009-2012 } \\
\hline $\mathrm{n}$ & 129 & 121 & 125 & 125 \\
\hline Mean milk yield (kg) & 31.12 & 31.40 & 31.93 & 32.25 \\
\hline SEM & 0.742 & 0.846 & 0.704 & 0.972 \\
\hline \multicolumn{5}{|c|}{ Purchased feed cost $2011^{2}$} \\
\hline $\mathrm{n}$ & 38 & 52 & 46 & 62 \\
\hline Mean milk yield (kg) & 31.32 & 32.10 & 32.42 & 31.35 \\
\hline SEM & 1.095 & 1.076 & 0.890 & 1.222 \\
\hline \multicolumn{5}{|c|}{ Purchased feed cost $2010^{2}$} \\
\hline $\mathrm{n}$ & 74 & 43 & 54 & 32 \\
\hline Mean milk yield (kg) & 30.91 & 31.02 & 31.23 & 34.44 \\
\hline SEM & 1.111 & 1.082 & 1.049 & 2.250 \\
\hline \multicolumn{5}{|l|}{ Purchased feed cost $2009^{2}$} \\
\hline $\mathrm{n}$ & 15 & 26 & 12 & 17 \\
\hline Mean milk yield $(\mathrm{kg})$ & 31.09 & 30.63 & 30.48 & 30.93 \\
\hline SEM & 1.533 & 2.758 & 2.912 & 2.964 \\
\hline
\end{tabular}

${ }^{1}$ The purchased feed costs were divided into 4 quartiles for when all the years were combined. The quartiles remained the same for each individual year analysis.

${ }^{2}$ Purchased feed cost resulted in no significant difference $(P>0.05)$ in milk yield. 
Table 4. The inclusion of 1 or more by-products on a commodity basis in a ration and the effect on milk yield $(\mathrm{n}=500)^{1}$

\begin{tabular}{|c|c|c|}
\hline Item & $\begin{array}{c}\text { No } \\
\text { by-product }\end{array}$ & $\begin{array}{l}\text { One or more } \\
\text { by-product }\end{array}$ \\
\hline \multicolumn{3}{|c|}{ Inclusion of by-product $2009-2012^{*}$} \\
\hline $\mathrm{n}$ & 332 & 168 \\
\hline Mean milk yield $(\mathrm{kg})$ & 31.21 & 32.59 \\
\hline SEM & 0.511 & 0.668 \\
\hline \multicolumn{3}{|c|}{ Inclusion of by-product 2009} \\
\hline $\mathrm{n}$ & 38 & 31 \\
\hline Mean milk yield (kg) & 30.29 & 31.35 \\
\hline SEM & 2.125 & 1.658 \\
\hline \multicolumn{3}{|c|}{ Inclusion of by-product $2010^{*}$} \\
\hline $\mathrm{n}$ & 147 & 56 \\
\hline Mean milk yield (kg) & 30.97 & 33.16 \\
\hline SEM & 0.741 & 1.369 \\
\hline \multicolumn{3}{|c|}{ Inclusion of by-product 2011} \\
\hline $\mathrm{n}$ & 128 & 70 \\
\hline Mean milk yield (kg) & 31.48 & 32.36 \\
\hline SEM & 0.751 & 0.776 \\
\hline
\end{tabular}

${ }^{1}$ By-products used in premixed feeds were not included in this analysis.

$* P<0.001$

study supports this data, finding the optimal forageto-concentrate ratio using IOFC with pasture-fed dairy cows (Baars, 1998). In a study on dual-purpose cows in coastal Mexico, Absalón-Medina et al. (2012) used the Cornell Net Carbohydrate and Protein System (Cornell University, Ithaca, NY) and IOFC to observe improvements in milk production over 3 lactations with the use of high-quality grass or grass supplemented with legume forages. It was found that high-quality forages or a combination of pasture and legume forages led to increased milk yield and IOFC compared with the traditional use of grass and concentrate supplementation. Feeding grass and legume forage diets increased the IOFC by $\$ 1,131$ across a 3 -lactation cow lifetime and rations using high-quality grass increased the IOFC by $\$ 866$ across a 3-lactation cow lifetime (Absalón-Medina et al., 2012).

Total feed costs in the top quartile $(\$ 6.27$ or more per cow per day) resulted in the highest $(P<0.01)$ IOFC for the combined years analyzed for 2009 to 2012 . For the individual year of 2010 , the top feed cost quartile also had the highest $(P<0.01)$ IOFC values. The individual years of 2009 and 2011 showed no difference $(P$ $>0.05$ ) in IOFC (Figure 3). In the combined years 2009 to 2012 and in 2010 , the milk yield was the highest $(P$ $<0.001)$ when feed costs were $\$ 6.27$ or higher. The individual years of 2009 and 2011 showed no difference $(P>0.05)$ in milk yield (Figure 4$)$.

Minimizing feed cost per cow per day did not result in the highest IOFC for this study. This supports the use of high-quality feed to improve IOFC and milk yield rather than the use of a least-cost ration. These findings are supported by Baars (1998), where feeding higher cost concentrates resulted in both higher milk production and a higher IOFC. The cost and quality of the feed can affect profit margins, making IOFC the best tool to monitor the feed quality's impact on milk yield as well as the overall cost of the ration. In contrast, Vibart et al. (2012) found that stocking density affected IOFC, but feed cost and pasture utilization did not affect IOFC. In a simulated model, feed prices did not affect profits on dairy farms (Congleton and King, 1984). In the current study, real farm data showed that feed cost can affect IOFC and milk yield, making margin management important to farm success. A study on organic dairies at the University of New Hampshire and University of Maine showed that in the organic feeding system, the use of pellets and corn silage on a commodity basis had a significantly higher cost compared with grass silage on a commodity basis at the University of New Hampshire, but not at the University of Maine (Marston et al., 2011). A bootstrap analysis showed that the grass silage (the lower-cost feed) had the highest IOFC and the corn silage (the higher-cost feed) had the lower IOFC. That study disagreed with the current study in that higher cost feeds had higher IOFC in the current study. However, Marston et al. (2011) investigated organic dairies, which likely had very different economic constraints from those in the current study.

\section{CONCLUSIONS}

Milk yield and IOFC were not affected by the level of purchased feed cost. Inclusion of by-products on a commodity basis showed increased milk production for these farms. Intermediate levels of forage costs resulted 


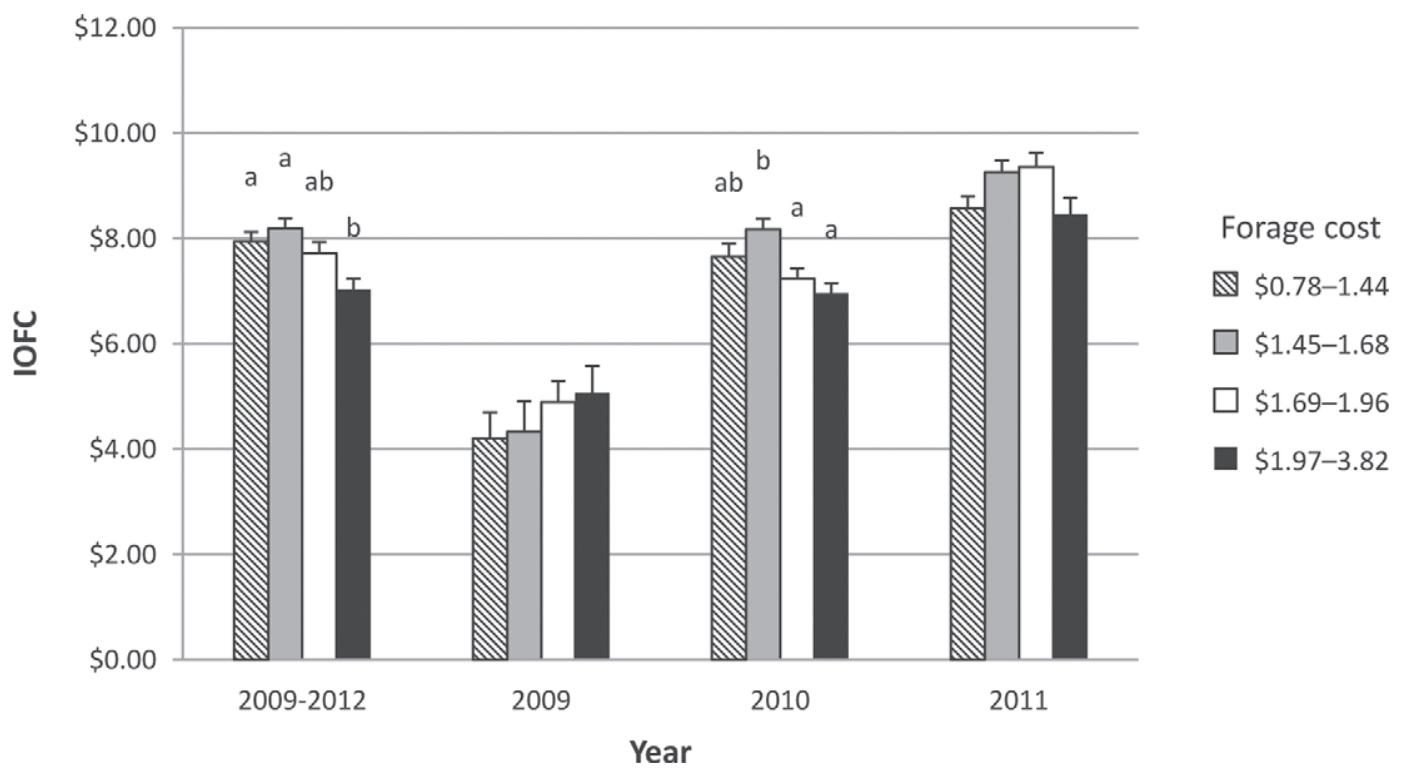

Figure 1. Ration forage cost ANOVA with cost quartiles for the impact of forage cost on income over feed cost (IOFC) for the combined years of 2009 to 2012 and the individual years of 2009, 2010, and 2011. Means with different letters (a and b) differ at $P<0.05$. The error bars are the positive standard error from the IOFC mean for each forage cost quartile. For combined years 2009 to 2012 , the $\mathrm{n}$ values in order of increasing quartile ranges were $127,124,124$, and 125 . Forage costs of $\$ 1.45$ to $\$ 1.68$ had significantly higher IOFC compared with the forage costs of $\$ 1.97$ to $\$ 3.82$. In 2009 , the $\mathrm{n}$ values in order of increasing quartile ranges were $6,11,25$, and 28 . No significant difference was observed between quartiles. In 2010, the $\mathrm{n}$ values in order of increasing quartile ranges were $62,62,41$, and 38 . The test for normality was non-normal data, with $P=0.019$. The ANOVA resulted in the forage cost of $\$ 1.45$ to $\$ 1.68$ having a higher IOFC compared with forage costs of $\$ 1.69$ to $\$ 3.82$. In 2011, the $\mathrm{n}$ values in order of increasing quartile ranges were $55,47,51$, and 45 . This resulted in an ANOVA result of $P=0.024$, but the Tukey analysis resulted in no significant difference $(P=0.071)$.

in the highest levels of both IOFC and milk yield, suggesting that IOFC needs to be monitored monthly to evaluate changes in management and rations. Higher total feed cost resulted in higher IOFC, suggesting that low feed cost alone did not ensure high net margins. The IOFC can be used effectively in assessing the ef-

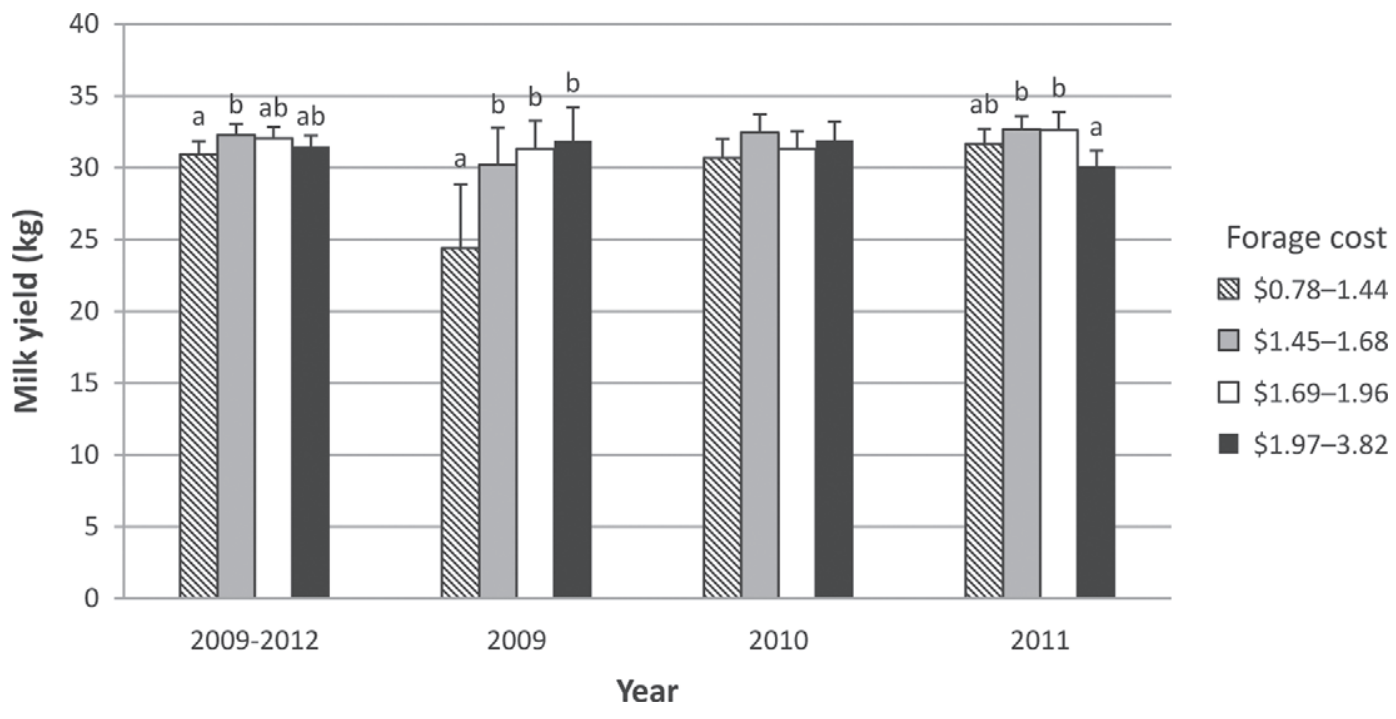

Figure 2. Ration forage cost ANOVA with cost quartiles for the impact of forage cost on milk yield for the combined years of 2009 to 2012 and the individual years of 2009, 2010, and 2011. Means with different letters (a and b) differ at $P<0.05$. The error bars are the positive standard error from the mean milk yield for each forage cost quartile. For combined years 2009 to 2012, the $\mathrm{n}$ values in order of increasing quartile ranges were $127,124,124$, and 125 . Forage costs of $\$ 0.78$ to $\$ 1.44$ had significantly lower milk yields. In 2009 , the $\mathrm{n}$ values in order of increasing quartile ranges were $6,11,25$, and 28 . Forage costs of $\$ 1.45$ to $\$ 1.96$ resulted in significantly higher mean milk yield. In 2010 , the $\mathrm{n}$ values in order of increasing quartile ranges were $62,62,41$, and 38 . This year resulted in no difference in milk yield with change in forage cost. In 2011 , the $\mathrm{n}$ values in order of increasing quartile ranges were $55,47,51$, and 45 . The forage costs of $\$ 1.97$ to 3.82 resulted in significantly lower milk yields. 


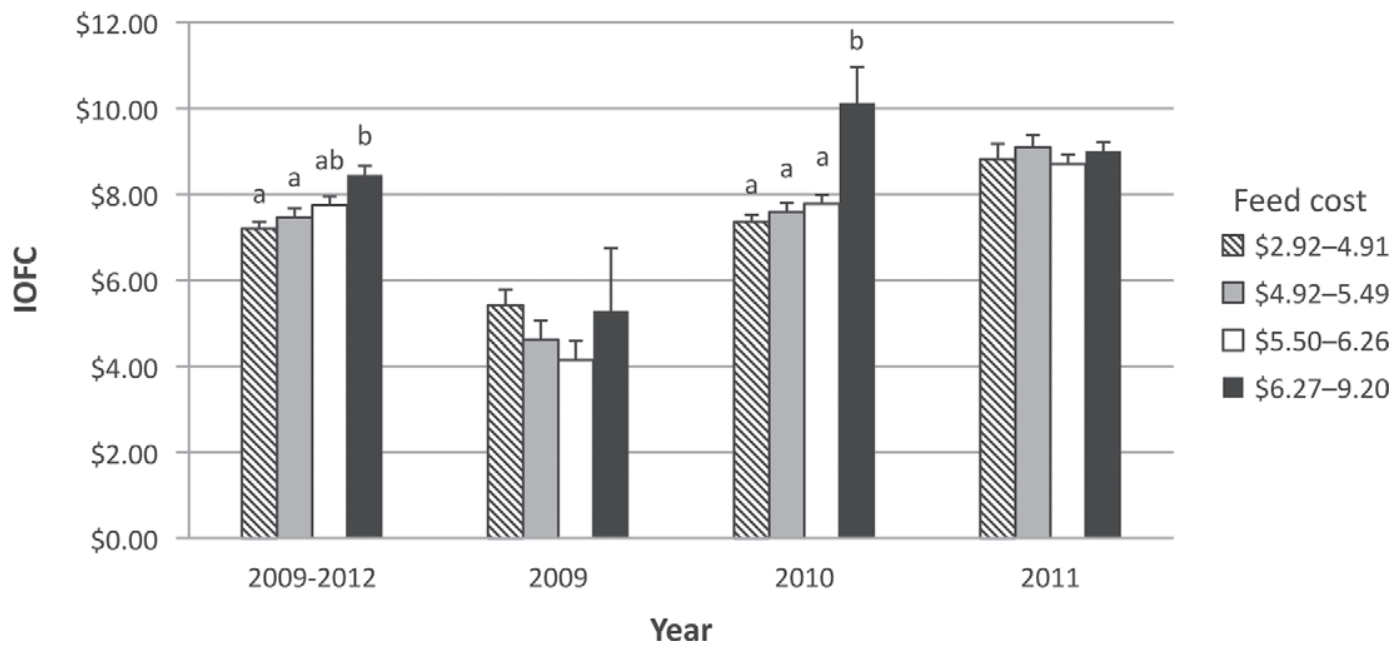

Figure 3. The total feed cost per cow per day in a ration and the income over feed cost (IOFC) using cost quartiles and an ANOVA for the combined years of 2009 to 2012 and the individual years of 2009, 2010, and 2011. Means with different letters (a and b) differ at $P<0.05$. The error bars are the positive standard error from the IOFC mean for each total feed cost quartile. For combined years 2009 to 2012 , the $\mathrm{n}$ values in order of increasing quartile ranges were $127,124,124$, and 125 . Feed costs of $\$ 6.27$ to $\$ 9.20$ resulted in higher IOFC compared with total feed costs of $\$ 2.92$ to $\$ 5.49$. In 2009 , the $\mathrm{n}$ values in order of increasing quartile ranges were $21,23,18$, and 8 . In 2009 , no effect on IOFC related to total feed cost was detected. In 2010, the $\mathrm{n}$ values in order of increasing quartile ranges were $92,65,40$, and 6 . The total feed cost quartile of $\$ 6.27$ to $\$ 9.20$ was significantly higher IOFC compared with the other ranges. In 2011 , the $\mathrm{n}$ values in order of increasing quartile ranges were $14,35,63$, and 86 . In 2010, no effect on IOFC in relation to total feed cost was observed.

fects of management and ration changes on net milk margin. Income over feed cost should be used with the producers' break-even IOFC to be effective in monitor- ing profitability. Inclusion of commodity by-products, intermediate levels of forage cost, and higher levels of total feed cost per cow per day resulted in both higher

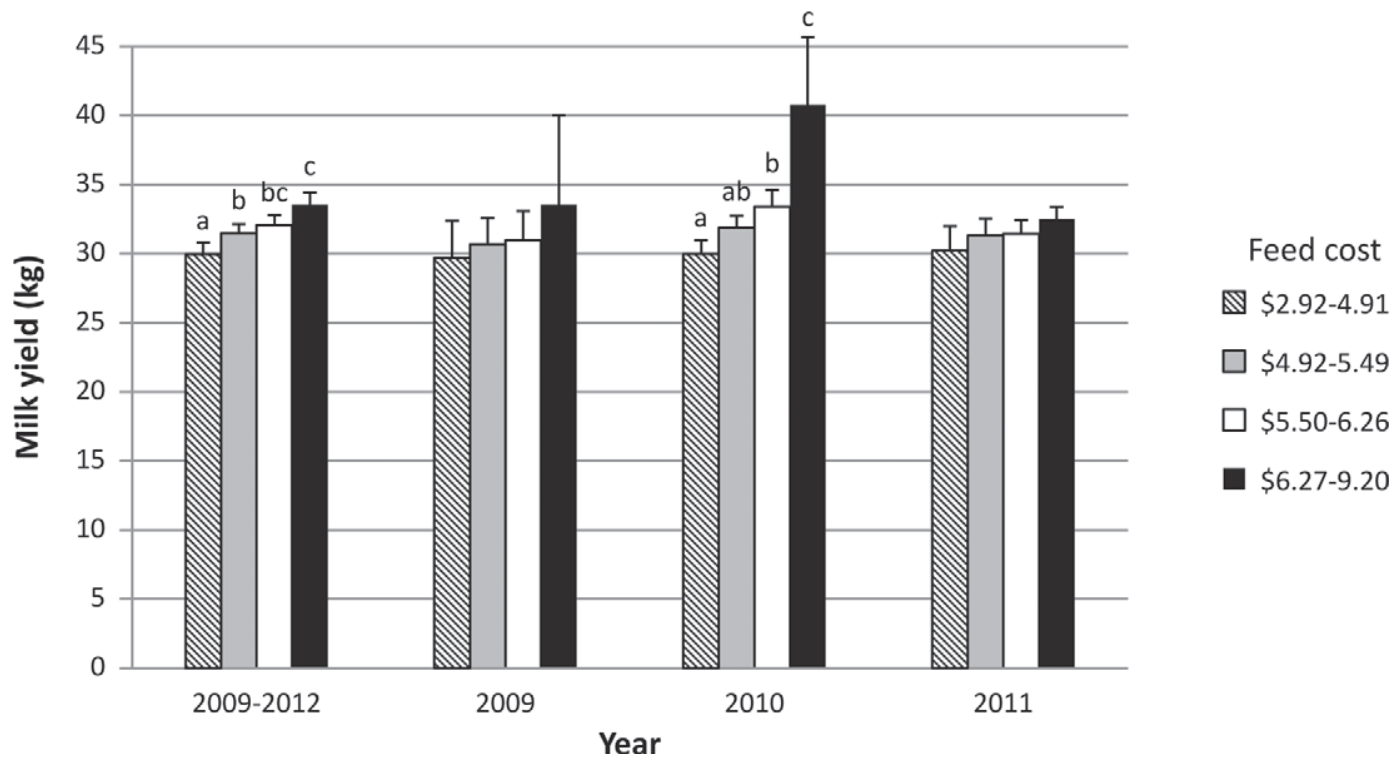

Figure 4. The total feed cost per cow per day in a ration and the impact on milk yield using cost quartiles and an ANOVA for the combined years of 2009 to 2012 and the individual years of 2009, 2010, and 2011. Means with different letters (a-c) differ at $P<0.05$. The error bars are the positive standard error from the mean milk yield for each total feed cost quartile. For combined years 2009 to 2012 , the $\mathrm{n}$ values in order of increasing quartile ranges were $127,124,124$, and 125 . The data are non-normal at $P=0.03$. Total feed costs of $\$ 6.27$ to $\$ 9.20$ resulted in higher milk yields compared with total feed costs of $\$ 2.92$ to $\$ 5.49$. In 2009 , the n values in order of increasing quartile ranges were $21,23,18$, and 8. In 2009, no effect of total feed costs on milk yield was observed. In 2010, the n values in order of increasing quartile ranges were 92 , 65, 40 , and 6. In 2010 , total feed costs of $\$ 6.27$ and higher resulted in significantly higher milk yields compared with total feed costs of $\$ 6.26$ or less. In 2011, the $\mathrm{n}$ values in order of increasing quartile ranges were $14,35,63$, and 86 . A trend $(P=0.058)$ was observed toward total feed costs of $\$ 6.27$ to $\$ 9.20$ resulting in the highest milk yield. 
milk yield and higher IOFC, suggesting that profit margin was affected by other factors in addition to feed cost per cow. Monitoring feed management on a regular basis and creating and maintaining the optimal ration and profit margin are needed.

\section{REFERENCES}

Absalón-Medina, V. A., C. F. Nicholson, R. W. Blake, D. G. Fox, F. I Juárez-Lagunes, E. G. Canudas-Lara, and B. L. Rueda-Maldonado. 2012. Economic analysis of alternative nutritional management of dual-purpose cow herds in central coastal Veracruz, Mexico. Trop. Anim. Health Prod. 44:1143-1150.

Baars, R. M. 1998. Nutrition management, nitrogen efficiency, and income over feed cost on dairy farms in Costa Rica. J. Dairy Sci. 81:801-806.

Bailey, K., T. Beck, E. Cowan, and V. Ishler. 2009. Managing income over feed cost. Accessed Feb. 21, 2014. http://extension.psu.edu/ animals/dairy/business-management/financial-tools/income-overfeed-cost/publications.

Bozic, M., J. Newton, C. S. Thraen, and B. W. Gould. 2012. Meanreversion in income over feed cost margins: Evidence and implications for managing margin risk by US dairy producers. J. Dairy Sci. 95:7417-7428

CME Group Inc. 2013. CME Group. Accessed Feb. 6, 2013. http:// www.cmegroup.com/.

Congleton, W. R., Jr., and L. W. King. 1984. Profitability of dairy cow herd life. J. Dairy Sci. 67:661-674.

Grasser, L. A., J. G. Fadel, I. Garnett, and E. J. DePeters. 1995. Quantity and economic importance of nine selected by-products used in California dairy rations. J. Dairy Sci. 78:962-971.

IBM Corp. 2012. IBM SPSS Statistics for Windows. Version 21.0. IBM Corp., Armonk, NY.

Ishler, V. 2012. Feed price list. Accessed Feb. 20, 2014. http://extension.psu.edu/animals/dairy/business-management/feed-price-list.
Ishler, V., T. Beck, K. Bailey, E. Cowan, and K. Dickson. 2013. Penn State income over feed cost tool. Accessed Feb. 20, 2014. http:/ extension.psu.edu/animals/dairy/business-management/financialtools/income-over-feed-cost/penn-state-income-over-feed-costtool/view.

Marston, S. P., G. W. Clark, G. W. Anderson, R. J. Kersbergen, M Lunak, D. P. Marcinkowski, M. R. Murphy, C. G. Schwab, and P. S. Erickson. 2011. Maximizing profit on New England organic dairy farms: An economic comparison of 4 total mixed rations for organic Holsteins and Jerseys. J. Dairy Sci. 94:3184-3201.

Maulfair, D., J. Heinrichs, and V. Ishler. 2011. Feed efficiency in lactating dairy cows and its relationship to income over feed costs. The Pennsylvania State University, University Park. Accessed Feb. 20, 2014. http://extension.psu.edu/animals/dairy/health/ nutrition/nutrition-and-feeding/diet-formulation-and-evaluation/ feed-efficiency-in-lactating-dairy-cows-and-its-relationship-toincome-over-feed-costs- 1 .

USDA-NASS (USDA National Agricultural Statistics Service). 2013. Statistics by subject. Crops and plants. Accessed Sep. 20, 2013. http://www.nass.usda.gov/Statistics_by_Subject/index.php.

Valvekar, M., V. E. Cabrera, and B. W. Gould. 2010. Identifying costminimizing strategies for guaranteeing target dairy income over feed cost via use of the Livestock Gross Margin dairy insurance program. J. Dairy Sci. 93:3350-3357.

Valvekar, M., J. P. Chavas, B. W. Gould, and V. E. Cabrera. 2011. Revenue risk management, risk aversion and the use of Livestock Gross Margin for Dairy Cattle insurance. Agric. Syst. 104:671678.

Vibart, R. E., S. P. Washburn, J. T. Green Jr., G. A. Benson, C. M Williams, D. Pacheco, and N. Lopez-Villalobos. 2012. Effects of feeding strategy on milk production, reproduction, pasture utilization, and economics of autumn-calving dairy cows in eastern North Carolina. J. Dairy Sci. 95:997-1010.

Wolf, C. A. 2010. Understanding the milk-to-feed price ratio as a proxy for dairy farm profitability. J. Dairy Sci. 93:4942-4948. 